\title{
Organic matter distribution in aggregate sizes of a mollisol under contrasting managements
}

\author{
M. Mandiola, G.A. Studdert*, G.F. Domínguez, C.C. Videla \\ Facultad de Ciencias Agrarias, UNMdP, Unidad Integrada Balcarce, C.C. 276, (7620) Balcarce, Buenos \\ Aires, Argentina. *Corresponding author: gstuddert@balcarce.inta.gov.ar
}

\begin{abstract}
Total and particulate organic matter content in different aggregate sizes can be used as an indicator of land use effect. We hypothesized that tillage reduction increases total (SOC) and particulate soil organic C (POC) contents and the stability of larger aggregates of high-SOC-content Mollisols. Three management systems (continuous pasture (Pp), and continuous cropping under conventional tillage (CT) and notillage (NT)) were evaluated. Oven dried soil samples (0-5 and 5-20 cm), were wet sieved through 2000, 250 and $50 \mu \mathrm{m}$ sieves after immersion (IW) and capillary (CW) wetting. Particulate organic matter $(>50 \mu \mathrm{m})$ was separated in both the whole soil and in each aggregate fraction, $\mathrm{SOC}$ and mineral associated organic $\mathrm{C}$ contents were determined, and POC was calculated by subtraction. Reduced soil disturbance (Pp and NT) yielded more SOC and POC in the whole soil and macroaggregates with higher stability $(\mathrm{Pp}>\mathrm{NT}>\mathrm{CT})$. Under Pp, macroaggregates showed the highest SOC and POC. Under NT, macroaggregates showed higher SOC and POC and aggregate stability than $\mathrm{CT}$ though lower than $\mathrm{Pp}$. Less tillage-induced disruption ( $\mathrm{Pp}$ and NT) led to higher SOC and POC contents in more stable macroaggregates but continuous no-tillage appeared not to be enough to reverse the effects of long lasting conventional management practices on these Mollisols.
\end{abstract}

Keywords: particulate organic matter, soil aggregates, aggregate stability, tillage systems. 


\section{Introduction}

Soil organic matter is one of the most important soil components, which determines most of soil quality (Carter, 2002). However, soil organic matter is highly sensitive to management practices (Wander, 2004) and its dynamics (Janzen, 2006), and consequently soil health, can be affected by how the soil is used. An increase in soil organic matter content helps reversing land degradation and often increases soil fertility and crop production (Weil and Magdoff, 2004).

Soil organic matter content reflects the balance between the humification and mineralization processes. Cropping-related decreases are directly proportional to the intensity of tillage operations (Janzen, 2006; Varvel and Wilhelm, 2010) and inversely proportional to the amount of residues returned to the soil (Kong et al., 2005; Domínguez et al., 2009; Varvel and Wilhelm, 2010). Residue amount and quality, timing as well as the way in which they are returned to the soil, and the factors that influence their transformation, can be managed through tillage operations and crop combinations (Janzen, 2006).

Particulate organic matter is a labile fraction constituted by partially decomposed plant material, fungal hyphae, spores, and pollen grains, with a particle size ranging between 50 and $2000 \mu \mathrm{m}$ (Wander, 2004). This fraction has a fast recycling rate and is associated with soil microbial activity and soil particle aggregation and aggregate stability (Six et al., 1998; 2000b). Thus, particulate organic matter is very sensitive to the changes produced by soil use and, therefore, its variation throughout time is more indicative of the effect of management practices than total organic matter (Carter, 2002; Fabrizzi et al., 2003). Likewise, its content can indicate the size of the easily mineralizable organic compartment and thus contribute to estimate potential nutrient (e.g. N) supply by soil (Álvarez and Álvarez, 2000; Fabrizzi et al., 2003; Oorts et al., 2007).
Soil organic matter is present both in inter-aggregate and in intra-aggregate spaces. Intra-aggregate organic matter is incorporated during the macro- and microaggregate formation process and is physically stabilized within them (Six et al., 2002; Oorts et al., 2007). Whether organic matter is located among aggregates or within them determines how easily it can be reached by microorganisms (Six et al., 2002) and, therefore, its mineralization rate (Cambardella and Elliott, 1993; Six et al., 2000a).

It has been postulated that microaggregates are formed mainly within macroaggregates. If macroaggregates are not disturbed, decomposing and fragmented organic material (particulate organic matter) within them would be gradually embedded with clay particles and microbial products, giving rise to new microaggregates in their interior. When cementing agents suffer microbial degradation and/or other breakdown action takes place, macroaggregates split apart freeing stable microaggregates which, if adequate conditions are present, afterwards join together again to form new macroaggregates. This recycling process is crucial to define both macroaggregate stability and soil organic matter protection within them (Six et al., 1998). Soil tillage causes physical disruption of macroaggregates thereby altering their formation cycle, thus increasing the loss of labile fractions (e.g. particulate organic matter) occluded within them (Six et al., 1998; Oorts et al., 2007) and reducing their stability, regardless of soil organic matter content (Eiza et al., 2006).

Aggregate stability decrease due to tillage is more pronounced for macroaggregates than for microaggregates. Macro- and microaggregate proportions in the soil and water stable aggregate size distribution are directly related to the intensity of disruption and rapidly respond to the aggressiveness and changes in 
soil management practices (Six et al., 2000b). Notillage leads to improved soil aggregation (Six et al., 1998; Oorts et al., 2007) and aggregate stability (Six et al., 2000b; Eiza et al., 2006) since it reduces physical disruption and promotes total and particulate soil organic matter accumulation, especially in surface layers (Puget and Lal, 2005).

Mollisols of the Southeastern area of Buenos Aires province, Argentina, show, in general, a loamy texture and a high soil organic matter content. However, long-term cropping has produced a decrease in both its labile and humified fractions and has modified their proportion in soil (Fabrizzi et al., 2003; Eiza et al., 2005; Sainz-Rozas et al., 2011). However, it has been demonstrated that, by conducting a thorough selection of crops and tillage operations, soil organic matter loss rates can be reduced regardless of the tillage system employed (Domínguez et al., 2009). Nevertheless, despite the scarce differences reported in total and particulate soil organic matter contents between no-tillage and conventional tillage with careful management (Diovisalvi et al., 2008; Domínguez et al., 2009), differences in crop behavior between notillage and conventional tillage are important mainly due to differences in $\mathrm{N}$ availability (Diovisalvi et al., 2008; Domínguez et al., 2009). This suggests that, although contrasting tillage systems do not differentially affect soil organic matter content of these soils, they do lead to different distribution of its labile fractions among aggregate categories with different aggregate stability affecting their exposure to mineralization. Therefore, it would be important to understand how different management systems modify soil organic matter allocation to aggregates having different size and stability. This would contribute to tillage selection decisions aimed at managing soil organic matter accumulation or loss and aggregate stability. Besides, changes in soil organic matter and aggregate stability are closely related to soil ability to supply $\mathrm{N}$ to crops and, consequently, its understanding and knowledge could be a sound contribution to finely tuning $\mathrm{N}$ fertility diagnose methods for an environmentally safe $\mathrm{N}$ fertilizer utilization.

We hypothesized that tillage reduction increases total and particulate soil organic matter contents and promotes the allocation of a larger proportion of them to larger aggregates, hence improving their stability. The aim of this work was to assess the influence of contrasting management (continuous pasture, continuous cropping under conventional tillage and continuous cropping under no-tillage) on total and particulate soil organic matter distribution in different aggregate size categories of a loam Mollisol of the Southeastern area of Buenos Aires province, Argentina.

\section{Material and Methods}

\subsection{Study site}

The experiment was carried out with soil samples taken from a long term crop-rotation and tillage-system experiment started in 1976 at the Unidad Integrada Balcarce, Balcarce, Buenos Aires province, Argentina (37 45' 09' S; 58 18' 48' W; $138 \mathrm{~m}$ above sea level). The soil is a complex of fine, mixed, thermic Typic Argiudoll (Soil Taxonomy) or Luvic Phaeozem (FAO Classification) (Mar del Plata Series, INTA, 1979) and fine, illitic, thermic Petrocalcic Paleudoll (Soil Taxonomy) or Petrocalcic Phaeozem (FAO Classification) (Balcarce series, petrocalcic horizon below $-0.7 \mathrm{~m}$, INTA, 1979) with less than $2 \%$ slope (low erosion). Surface horizon characteristics of the soil complex are shown in Table 1. The climate in this area is classified as mesothermal subhumid-humid (according to Thornthwaite classification) or as temperate humid without dry season (according to Köppen classification) (A. Irigoyen, personal communication, 2010). Median annual rainfall, potential evapotranspiration and annual mean air temperature (1976-2005) are 950 
$\mathrm{mm} \mathrm{yr} r^{-1}, 946 \mathrm{~mm} \mathrm{yr}^{-1}$ and $13.9^{\circ} \mathrm{C}$ (maximum $19.6^{\circ} \mathrm{C}$ and minimum $8.3^{\circ} \mathrm{C}$ ), respectively (source: Unidad Integrada Balcarce's weather station, $37^{\circ} 45^{\prime} \mathrm{S}, 58^{\circ} 18^{\prime}$ $\mathrm{W}, 130 \mathrm{~m}$ above sea level).

Table 1. Some surface parameters (A horizon) of the soil complex under study (INTA, 1979).

\begin{tabular}{ll}
\hline Thickness $(\mathrm{cm})$ & 27.5 \\
Texture & Loam \\
Parent material & Loess \\
Particle size distribution $\left(\mathrm{g} \mathrm{kg}^{-1}\right)$ & \\
$\quad$ Clay & 235 \\
$\quad$ Silt & 339 \\
$\quad$ Sand & 429 \\
Organic C $\left(\mathrm{g} \mathrm{kg}^{-1}\right)$ & 37.3 \\
Organic N $\left(\mathrm{g} \mathrm{kg}^{-1}\right)$ & 3.23 \\
$\mathrm{pH}\left(1: 2: 5 \mathrm{in} \mathrm{water}^{-1}\right)$ & 6.20 \\
$\mathrm{CEC}$ & 24.7 \\
$\mathrm{Na}^{+}(\mathrm{cmol} \mathrm{kg}$ & \\
$\mathrm{K}^{+}(\mathrm{cmol} \mathrm{kg}$ & \\
$\mathrm{Ca}^{+}(\mathrm{cmol} \mathrm{kg})$ & 0.34 \\
$\mathrm{Mg}^{+}\left(\mathrm{cmol} \mathrm{kg}^{-1}\right)$ & 2.31 \\
$\mathrm{Base} \mathrm{saturation}(\%)$ & 13.3 \\
\hline
\end{tabular}

The experimental design was a completely randomized block design with a split-plot treatment arrangement, three replications, and $17.5 \mathrm{~m} \mathrm{x} 7.5 \mathrm{~m}$ (131.3 $\left.\mathrm{m}^{2}\right)$ experimental units, Nitrogen fertilization $(0,60$, 120 , and $180 \mathrm{~kg} \mathrm{~N} \mathrm{ha}^{-1}$ ) was assigned to the sub-plots and management systems were assigned to the main plots. Between 1976 and 1993 the management systems comprised different crop-pasture rotations under conventional tillage (Studdert et al., 1997). Since 1994, the crop rotation scheme has been modified and the tillage system has been included as a classification variable resulting in seven management systems: continuous pasture $(\mathrm{Pp})$, continuous cropping under conventional tillage $(\mathrm{CT})$, continuous cropping under no-tillage (NT), 50\% pasture - 50\% copping under conventional tillage and under no-tillage, and $25 \%$ pasture $-75 \%$ cropping under conventional tillage and under no-tillage. Given the fact it has been shown that there has been no difference in soil organic content due to $\mathrm{N}$ fertilization (Studdert et al., 1997; Eiza et al., 2005; Domínguez et al., 2009), and that the objective of this work was to analyze truly contrasting management situations, samples were taken from only the fertilized (120 $\left.\mathrm{kg} \mathrm{N} \mathrm{ha}^{-1}\right)$ experimental units of three out of the seven management systems comprised in the experiment: Pp, CT and NT. Since 1994, the crop sequence in CT and NT has been maize (Zea mays L.) - soybean (Glycine max (L.) Merr) - spring wheat (Triticum aestivum L.). Plant species sown in Pp main plots were tall fescue (Festuca arundinacea L.) and white clover (Trifolium repens L.) and were not grazed. Both CT and NT plots had been under continuous cropping under conventional tillage between 1976 and 1993 but, since 1994, CT plots continued under conventional tillage whereas some plots were switched to no-tillage. Conventional tillage comprised moldboard plowing, disking, and field cultivation/spike harrowing with the minimum operations necessary to get an acceptable seed bed and to leave some cover during March and April when most erosive rainfalls occur. During fallow, weeds were controlled under NT with glyphosate at recommended rates.

Composite soil samples (10 sub-samples per sample at random in each experimental unit) were taken in February 2009 with a $4.44 \mathrm{~cm}$ diameter core sampler at two depths $(0-5$ and $5-20 \mathrm{~cm})$. The results were also shown for the $0-20 \mathrm{~cm}$ layer calculated as the weighted mean of the values obtained for $0-5 \mathrm{~cm}$ and 5-20 $\mathrm{cm}$ layers. Soil water content at sampling time was close to field capacity. Samples were carefully handdisrupted so that soil passed through an $8 \mathrm{~mm}$ sieve and then dried in a forced-air oven at $50{ }^{\circ} \mathrm{C}$. 


\subsection{Aggregate size distribution and stability analyses}

Aggregate size separation was carried out through a modification of the method proposed by Six et al. (1998). This method consists of sequentially sieving soil through different mesh sieves (2000, 250, and 50 $\mu \mathrm{m}$ sieves) in water after two different methods consisting of re-wetting the aggregates: capillary $(\mathrm{CW})$ and by immersion (slaking, IW). Capillary wetting consisted of placing $100 \mathrm{~g}$ of dry aggregates in a pan on wet filter paper for $24 \mathrm{~h}$ in order for them to reach water content close to field capacity. Afterwards, rewetted aggregates were submerged in water within the first sieve $(2000 \mu \mathrm{m})$ to start the sieving process. For the IW, another $100 \mathrm{~g}$ of dry aggregates were directly submerged in water within the first sieve $(2000 \mu \mathrm{m})$. In both cases (CW and IW), the sieving process was started 5 min after submerging the aggregates in water.

Each sieving was performed by moving the sieve up and down $3 \mathrm{~cm}$ submerged in water at a rate of 50 cycles in $2 \mathrm{~min}$. In order to ensure the homogeneity of the process for all sievings, a mechanical device was especially built for this purpose. The first sieving was done with the $2000 \mu \mathrm{m}$ sieve and, after the sieving time, the aggregates that remained on it were backwashed off the sieve into a plastic pot and $5 \mathrm{~mL}$ of 2 $\mathrm{N}$ calcium chloride solution were added to speed up soil flocculation. On the other hand, the water containing soil that passed the $2000 \mu \mathrm{m}$ sieve was carefully poured through the $250 \mu \mathrm{m}$ sieve and afterwards, the sieving process and the back washing was done as described above. The same process was repeated through the $50 \mu \mathrm{m}$ sieve and the fraction that passed this sieve was discarded. After $24 \mathrm{~h}$, the supernatant in the plastic pots was extracted with a vacuum pump and the soil dried in a forced-air oven at $50{ }^{\circ} \mathrm{C}$ up to constant weight. The weight of the fraction $<50 \mu \mathrm{m}$ was obtained by calculating the difference between the initial amount of aggregates $(100 \mathrm{~g})$ and the summation of the weights of the other fractions ( $>2000,250-2000$, and 50-250 $\mu \mathrm{m})$. Given the fact that the soil under study does not contain coarse sand (INTA, 1979) and that there were no texture differences neither among management systems nor between depths (data not shown), aggregate size weights were not corrected by sand content as indicated by Six et al. (1998).

An aggregate stability indicator could be calculated by comparing aggregate distribution represented by its mean weight diameter (MWD) before and after disruption. The aggregate distribution obtained after $\mathrm{CW}$ was considered as the initial distribution because maximum aggregate yield is achieved after rewetting the soil to a moisture content of field capacity. The aggregate distribution obtained after IW was taken as the aggregation level after disruption (Six et al., 2000b). The MWD was calculated from aggregates recovered from each group of sievings for each wetting method (CW and IW), according to

$$
\text { MWD }=\sum_{i=1}^{n} x_{i} w_{i}
$$

where $\mathrm{i}$ is each aggregate size fraction, $\mathrm{n}$ is the total number of aggregate size fractions including $<50$ $\mu \mathrm{m}(4), x_{i}$ is the mean diameter of the $i$-th size fraction $(\mu \mathrm{m})$ calculated as the arithmetic mean of the opening of two successive sieves (8000 and $2000 \mu \mathrm{m} ; 2000$ and $250 \mu \mathrm{m} ; 250$ and $50 \mu \mathrm{m} ; 50$ and $0 \mu \mathrm{m})$, and $\mathrm{w}_{\mathrm{i}}$ is the proportion of the $\mathrm{i}$-th size fraction $\left(\mathrm{g} \mathrm{g}^{-1}\right)$. The difference between MWD for CW and for IW is the change in MWD ( $\mathrm{MWD}$ ) and was used as an indicator of aggregate stability.

\subsection{Soil organic matter analysis}

The particulate soil fraction ( $>50 \mu \mathrm{m}$, particulate organic matter + sand) was separated by wet sieving (Cambardella and Elliott, 1992) in both the whole soil 
and in each of its aggregate size fractions. The soil $(10 \mathrm{~g})$ was dispersed in $30 \mathrm{~mL}$ of a solution of sodium hexametaphosphate $(0.5 \%)$ by shaking for $15 \mathrm{~h}$ with a homemade reciprocal shaker. Afterwards, the suspension was passed through a $50 \mu \mathrm{m}$ sieve that retained the sand and particulate organic matter. The suspension of the silt+clay fraction together with the associated organic matter was collected in a beaker and 5 $\mathrm{mL}$ of $2 \mathrm{~N}$ calcium chloride solution were added to speed up flocculation. After 24-36 h, the supernatant was extracted with a vacuum pump. Afterwards, the flocculated material was dried in a forced-air oven at $50{ }^{\circ} \mathrm{C}$ up to constant weigh and then ground with mortar and pestle for analysis.

Total organic C (SOC) content was determined in the whole soil and in the $>2000,2000-250$ and 250-50 $\mu \mathrm{m}$ aggregate size fractions, and associated organic $\mathrm{C}$ (AOC) content was determined in the mineral-associated-organic-matter fraction of the whole soil and of each aggregate size fraction. Total soil organic $\mathrm{C}$ and $\mathrm{AOC}$ contents were assessed through wet oxidation with potassium dichromate in the presence of sulfuric acid at $120^{\circ} \mathrm{C}$ for $90 \mathrm{~min}$ (Schlichting et al., 1995). The color intensity of the solution was measured using a UV vis spectrophotometer (SP-2102UV, Spectrum, China) at $578 \mathrm{~nm}$ wave length. Particulate organic $\mathrm{C}$ content of both the whole soil and the $>2000,2000-250$ and $250-50$ $\mu \mathrm{m}$ aggregate size fractions was calculated as the difference between their SOC and their AOC contents. Carbon content of the $<50 \mu \mathrm{m}$ aggregate size fraction was calculated as the difference between $\mathrm{AOC}$ of the whole soil and the summation of the AOC content of each of the other aggregate size fractions. Aggregate size fraction SOC, AOC and POC contents were expressed both in concentration units with respect to the whole soil mass (referred to as relative concentration, $\mathrm{g} \mathrm{C} \mathrm{kg}^{-1}$ soil) and in concentration units with respect to the mass of the respective aggregate size fraction mass (referred to as absolute concentration, $\mathrm{g} \mathrm{C} \mathrm{kg}^{-1}$ aggregates). Since the $<50 \mu \mathrm{m}$ aggregate size fraction was not recovered, its absolute $\mathrm{C}$ concentration could not be determined.

Results were statistically analyzed through analysis of variance with a mixed model where management system and aggregate size fraction were fixed effects, and block was the random effect. The MIXED procedure of the Statistical Analysis System (SAS) (Litell et al., 2006) was used. The significance level was set to $5 \%$. When the analysis of variance showed the existence of significant differences means were compared using the least significant difference test.

\section{Results and discussion}

\subsection{Aggregate size distribution and stability}

Aggregate size distribution after CW (Figure 1A) showed a different pattern than after IW (Figure 1B). In general, after $\mathrm{CW}$ aggregate size distribution was skewed towards larger size aggregates (macroaggregates, $>250 \mu \mathrm{m}$ ), whereas after IW, it was skewed towards smaller aggregate sizes (microaggregates, $50-250 \mu \mathrm{m}$ ) because of the breaking down of larger aggregates into the smaller categories. 

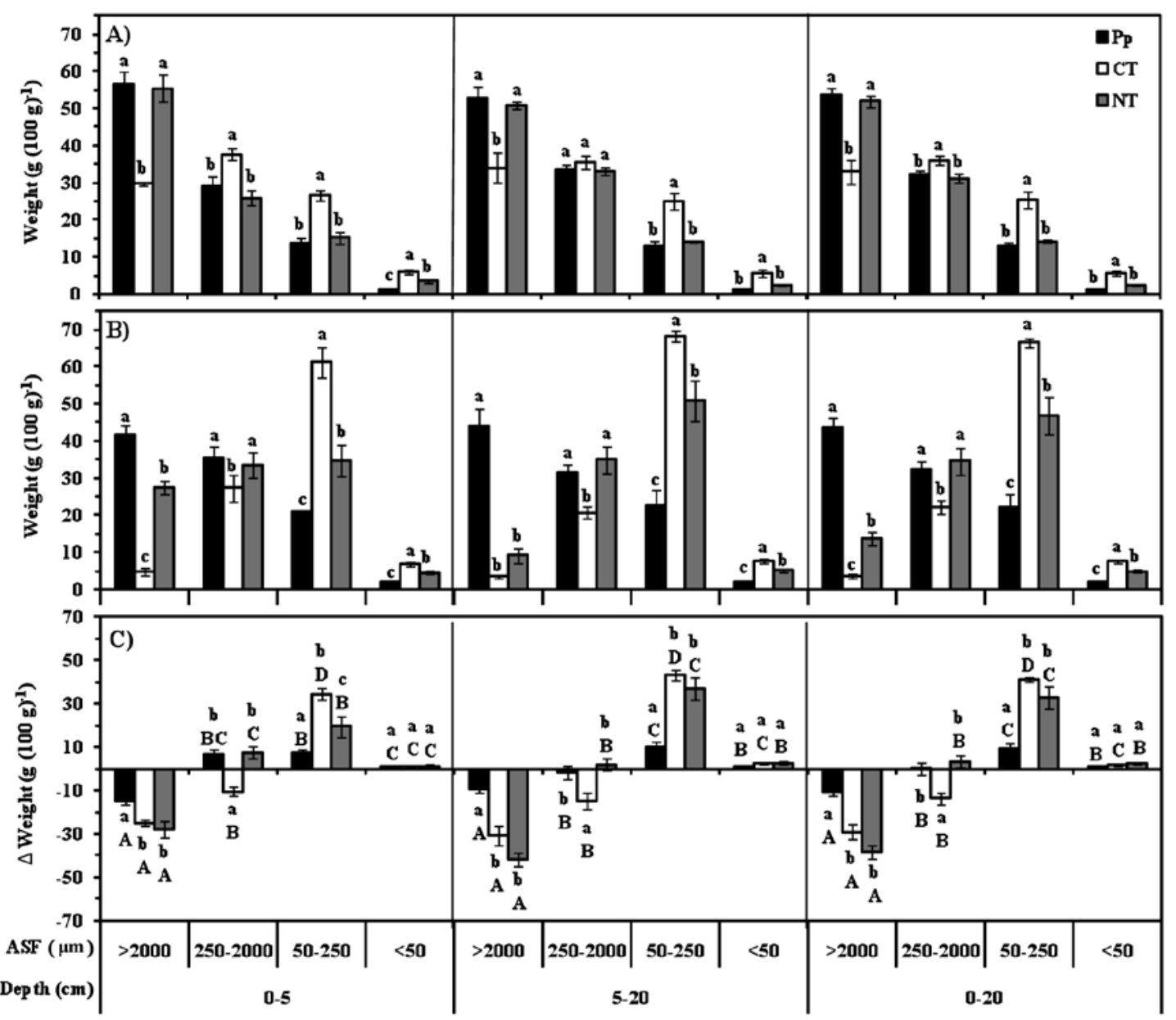

Figure 1. Aggregate size distribution (aggregate size fraction, ASF) at three depths, for three management systems (MS) and after two wetting procedures: A) capillary wetting (CW), B) immersion wetting (IW), and C) the difference between IW and CW. Pp: continuous pasture, CT: continuous cropping under conventional tillage, NT: continuous cropping under no-tillage. Vertical bars in each column indicate standard error of the mean. Different lower case letters indicate significant differences among MS $(p<0.05)$ for each ASF and depth. In C) different upper case letters indicate significant differences among ASF $(p<0.05)$ for each MS and depth. 
Both Pp and NT (Figure 1) showed significantly higher amount of aggregates $>2000 \mu \mathrm{m}$ than $\mathrm{CT}$ at all depths and for both wetting procedures. After $\mathrm{CW}$ (Figure 1A), the amounts of almost all aggregate sizes under Pp and NT were not significantly different between them but different from CT, in most cases significantly. However, after IW, the proportion of aggregates $>2000 \mu \mathrm{m}$ under NT was lower than after $\mathrm{CW}$ and remained significantly higher than $\mathrm{CT}$ although significantly lower than Pp (Figure 1B). On the other hand, IW provoked a marked breakdown of aggregates $>250 \mu \mathrm{m}$ under CT with a strong significant increase of the 50-250 $\mu \mathrm{m}$ fraction (Figure $1 \mathrm{~B}$ and $1 \mathrm{C})$. The amount of 50-250 $\mu \mathrm{m}$ aggregates under NT after IW also increased and turned higher than Pp though lower than CT (Figure 1B and 1C). In agreement with Cambardella and Elliott (1993), the $<50 \mu \mathrm{m}$ fraction was very small, being $\mathrm{Pp}<\mathrm{NT}<$ $\mathrm{CT}$ and $\mathrm{CT}$ significantly higher in all cases (Figure $1 \mathrm{~A}$ and 1B). Likewise, the difference in this fraction between wetting procedures was scarce (Figure 1C). Hence, changes in aggregate size distribution due to IW resulted in an increment of the 50-250 $\mu \mathrm{m}$ fraction but not in the $<50 \mu \mathrm{m}$ fraction, which confirms that microaggregates are much more stable than macroaggregates (Cambardella and Elliott, 1993).

In all cases (management systems and depths), the proportion of aggregates $>2000 \mu \mathrm{m}$ after IW showed the highest decrease (Figure 1C). However, this reduction was significantly lower under Pp, whereas it was not different between CT vs. NT. Wetting Pp aggregates by immersion did not reduce the proportion of any other aggregate size fraction (Figure 1C). On the other hand, the decrease in macroaggregates $(>250$ $\mu \mathrm{m})$ under CT resulted in a significantly higher increment in the 50-250 $\mu \mathrm{m}$ aggregates than under NT only in the top $-5 \mathrm{~cm}$ although it also tended to be higher at $5-20 \mathrm{~cm}$ and at $0-20 \mathrm{~cm}$ depths (Figure 1C). These results show a clear difference among management systems in aggregate stability facing different disruption forces associated with each wetting procedure.

Continuous pasture is the management system that showed the significantly highest aggregate stability, i.e. the lowest $\triangle \mathrm{MWD}$ (Figure 2). This agrees with the results reported by Six et al. (2000a) for grasslands and by Eiza et al. (2006) for cultivated pastures. Higher aggregate stability under $\mathrm{Pp}$ is given by a better aggregation and a higher proportion of stable macroaggregates (Figure 1). Growth of pastures, especially when composed of grasses, is associated with the growth of very dense and fibrous root systems that favors and facilitates macroaggregate formation and contributes to their stabilization (Bronick and Lal, 2005), leading to an improvement of soil physical conditions (Studdert et al., 1997; Ernst and SiriPrieto, 2009). 


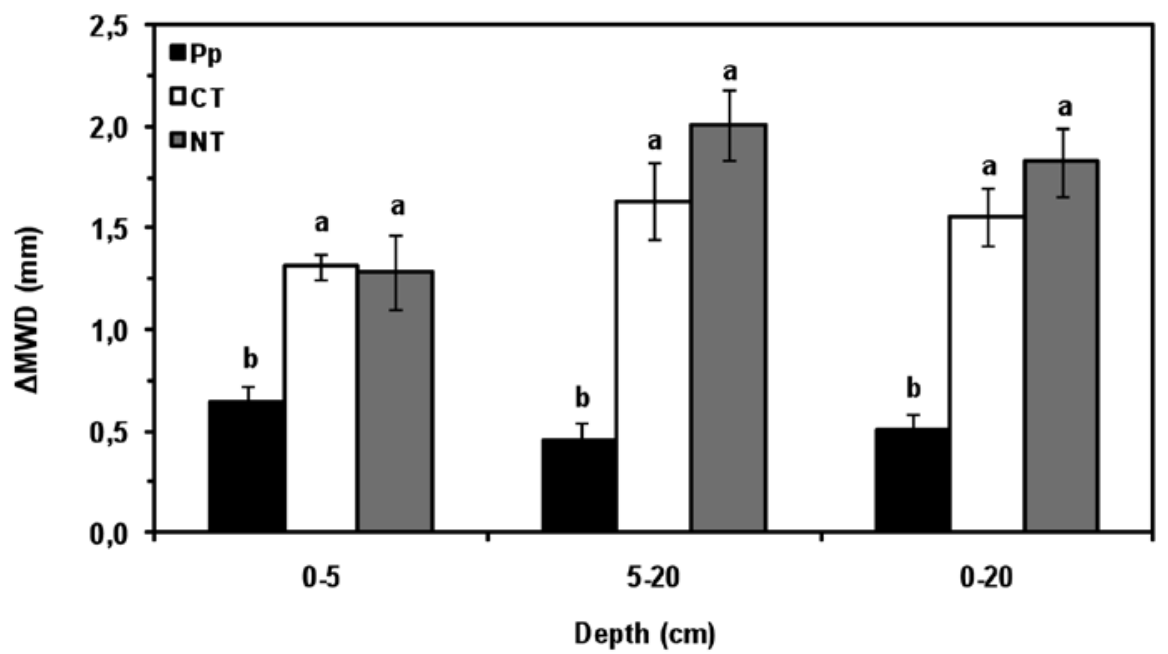

Figure 2. Mean weight aggregate diameter change $(\triangle \mathrm{MWD})$ due to sieving after two wetting procedures (capillary and by immersion) for three management systems (Pp: continuous pasture, CT: continuous cropping under conventional tillage, NT: continuous cropping under no-tillage) and at three depths. Vertical bars in each column indicate standard error of the mean. Different letters next to each column for each depth indicate significant differences among management systems $(p<0.05)$.

Six et al. (2000a), Eiza et al. (2006) and Domínguez et al. (2008) reported that conservation systems, similar to NT, showed higher $\triangle \mathrm{MWD}$ than grassland or cultivated pastures but higher aggregate stability (lower $\triangle \mathrm{MWD}$ ) than highly disturbed systems (similar to CT). High aggregation and stability play a key role concerning soil organic matter decrease associated with soil use. Aggregates create a physical barrier to microorganisms' access and prevent soil organic matter degradation (Six et al., 2002). Tillage breaks macroaggregates and reduces their stability since it aggressively disrupts the soil and exposes soil organic matter fractions to mineralization that would have been otherwise protected within them. These fractions join together microaggregates to form macroaggregates and are responsible for microaggregate re-cycling within the large ones (Six et al., 1998). Management practices that reduce soil disturbance and increase soil cover and $\mathrm{C}$ input, just like Pp and NT, contribute to soil aggregation and stabilization (Bronick and Lal, 2005; Eiza et al., 2006). However, Figure 2 shows that there were no significant differences in $\triangle \mathrm{MWD}$ between $\mathrm{CT}$ and NT at any depth. The results shown in Figure 2 for NT were not expected after so many years under no -tillage (15 yr). However, those results are consistent with other authors who reported that similar soils under continuous no-tillage after long lasting aggressive management, were not able to recompose the aggregate stability of their arable layer (Domínguez et al., 2008) with the exception of the top $5 \mathrm{~cm}$ (Andersen, A., personal communication). 


\subsection{Organic carbon in the whole soil}

Figure 3 shows soil SOC, AOC, and POC contents for all three management systems. Soil organic $\mathrm{C}$ content under $\mathrm{Pp}$ at $0-5 \mathrm{~cm}$ depth was significantly higher than under CT and NT. Even though SOC contents in the top layer were not statistically different between the management systems under cropping, NT showed higher SOC than CT. On the other hand, both at 5-20 $\mathrm{cm}$ and at $0-20 \mathrm{~cm}$ depths, the SOC, AOC and POC among management systems were similar to those at the surface layer, but Pp and NT did not statistically differ between them and both had significantly higher
SOC content than CT. Under Pp and NT, soil disturbance by tillage is reduced and there is either green plant material or residues on surface. This, together with the lower surface soil temperature and increased biological activity generally occurring under NT, has been reported as causing an increment of SOC content in the surface layer with respect to those management systems where soil is tilled (Six et al., 2002; Puget and Lal, 2005). As reported in the literature (Cambardella and Elliott, 1992; Eiza et al., 2005; Domínguez et al., 2009), mineral-associated organic $C$ content was not significantly different among management systems at all three depths.

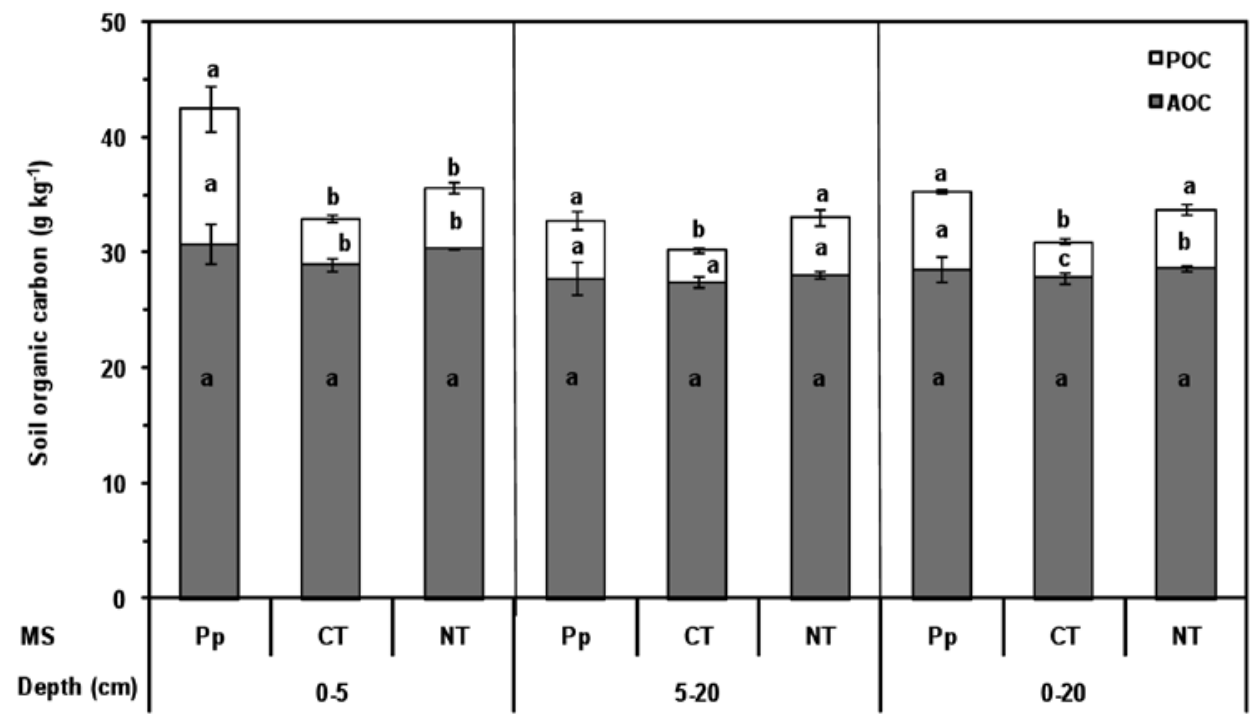

Figure 3. Mineral associated (AOC), particulate (POC), and total (AOC + POC), organic carbon in the whole soil for three management systems (MS) (Pp: continuous pasture, CT: continuous agriculture under conventional tillage, NT: continuous agriculture under no-tillage) at three depths. Vertical bars in each column indicate standard error of the mean. Different letters next or within each part of each column for each depth indicate significant differences among MS for each SOC fraction $(p<0.05)$. 
Particulate organic $\mathrm{C}$ content showed different trends for the different layers (Figure 3). In the surface layer, POC was significantly higher under Pp than under NT and CT. On the other hand, even though the difference was not significant, NT presented higher POC than CT. These results confirm the high sensitivity of POC to show changes due to management (Álvarez and Álvarez, 2000; Fabrizzi et al., 2003), especially in the surface layer (Puget and Lal, 2005; Diovisalvi et al., 2008; Domínguez et al., 2009). Likewise, at 5-20 cm depth, even though differences were not significant, Pp and NT also showed higher POC than $\mathrm{CT}$. This agrees with the information reported by $\mathrm{Di}-$ ovisalvi et al. (2008), who found that in similar soils, POC and SOC tended to be higher under no-tillage than under conventional tillage both in the $0-5 \mathrm{~cm}$ and in the 5-20 cm layers. Likewise, Eiza et al. (2005) informed that with crop-pasture rotations, POC increased in the arable layer along the period under pasture. Higher POC contents observed in both layers (0-5 and 5-20 cm, Figure 3), resulted in significant differences among management systems in the arable layer $(0-20 \mathrm{~cm})$ and treatments could be ordered as $\mathrm{Pp}$ $>\mathrm{NT}>\mathrm{CT}$ according to the POC content in the arable layer. This agrees with other authors (Fabrizzi et al., 2003; Diovisalvi et al., 2008) who worked on similar soils with long-cropping history under no-tillage and conventional tillage, and with Eiza et al. (2005) who compared continuous cropping under no-tillage and conventional tillage with continuous pasture.

Higher POC and SOC contents under Pp (Figure 3) could have contributed to its higher aggregate stability at all depths (Figures 1C and 2). Eiza et al. (2006) reported a positive significant relationship between POC and aggregate stability index when considering management systems with low soil disturbance (no-tillage and pastures). However, that relationship was not significant when the soil suffered aggressive disturbance (conventional tillage). In this experience, despite the trend to a higher POC content under NT at all three depths (Figure 3), aggregate stability was not higher than CT and was significantly lower than Pp (Figure 2). However, it is worthwhile to recall that NT showed a trend to a higher stability of macroaggregates $(>250 \mu \mathrm{m})$ than $\mathrm{CT}$ in the three layers which resulted in a lower increment of microaggregates after IW (Figure 1C). This suggests that higher POC content under NT might also have a different distribution among aggregate size classes than under CT.

\subsection{Organic carbon in the aggregate size fractions}

Relative concentrations of SOC, AOC and POC in aggregate size categories $\left(\mathrm{g} \mathrm{C} \mathrm{kg}^{-1}\right.$ soil), showed the same distribution as the aggregate size distribution (Figure 1) for both wetting procedures (data not shown). This had been already reported by other authors (Cambardella and Elliott, 1993; Six et al., 2000a) who observed that the amount of soil present in each aggregate size fraction determined their SOC, AOC, or POC contents expressed per unit of whole soil mass (relative concentration). In order to avoid the effect of the mass of the different aggregate size categories on the expression of SOC, AOC, and POC concentration, it is necessary to analyze their absolute concentration (amount of SOC, AOC, or POC per unit weight of the corresponding aggregate fraction). Figure 4 shows SOC absolute concentration for each aggregate size fraction separated by sieving after each wetting procedure. In general, SOC contents were quite similar among aggregate sizes and management systems, and between wetting procedures. 

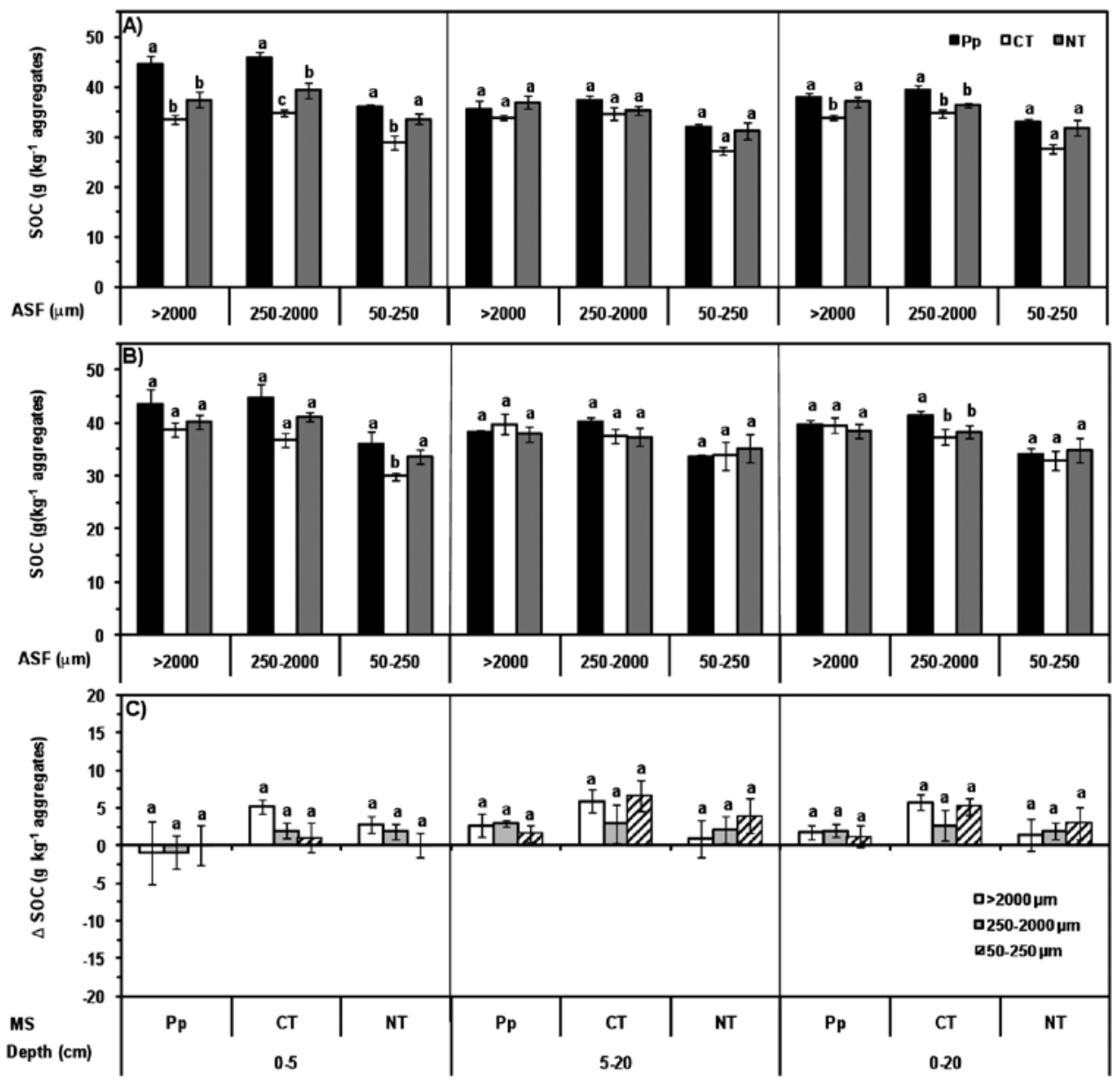

Figure 4. Total organic carbon (SOC) absolute concentration in different aggregate sizes (aggregate size fraction, ASF) for two wetting procedures: A) capillary and B) by immersion, and C) change in SOC absolute concentration $(\triangle \mathrm{SOC})$ at three depths and for three management systems (MS): Pp: continuous pasture, $\mathrm{CT}$ : continuous cropping under conventional tillage, NT: continuous cropping under no-tillage. Vertical bars in each column indicate standard error of the mean. Different letters next to each column for each ASF (A and B) or MS (C) and for each depth indicate significant differences among ASF or MS, respectively $(p<0.05)$.

Total SOC contents in the different aggregate categories after CW (Figure 4A) were lower than after IW (Figure 4B). Therefore, SOC absolute concentration changes due to the wetting procedure (IW$\mathrm{CW}$ ) were positive (Figure 4C). Regardless of the size, the aggregates that remained intact after siev- ing following IW were those with a higher SOC content which resulted in no difference among management systems (Figure 4B). The differences in SOC content between IW and CW (Figure 4C) could be ordered in general $\mathrm{Pp}<\mathrm{NT}<\mathrm{CT}$ at all three depths and for all the aggregate sizes. This 
could be related to the changes in aggregate size proportions due to IW (Figure 1C).

After CW, all aggregate categories $(>2000,250-$ 2000, and 50-250 $\mu \mathrm{m}$ ) under Pp and NT showed higher POC content than under CT (Figure 5A), although the differences were significant only at $0-5 \mathrm{~cm}$ depth.
On the other hand, at $0-5 \mathrm{~cm}$, POC content of the aggregates that resulted from sieving after IW (Figure 5B) was higher under Pp and, to a lower extent, under NT. The differences among management systems in POC content were lower at 5-20 and at $0-20 \mathrm{~cm}$ depths (Figure 5B).
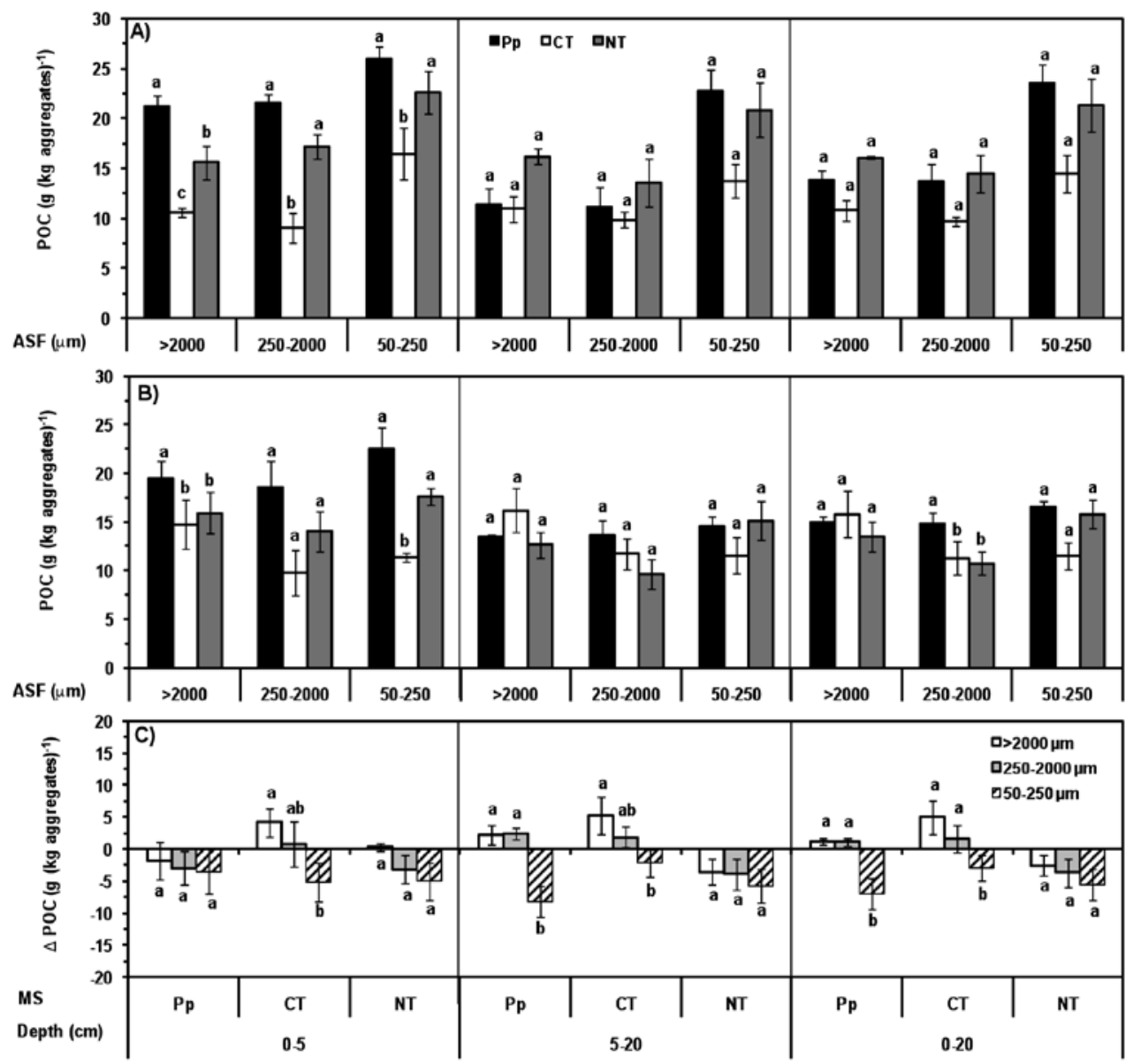

Figure 5. Particulate organic carbon (POC) absolute concentration in different aggregate sizes (aggregate size fraction, ASF) and for two aggregate wetting procedures: A) capillary and B) by immersion, and C) change in POC absolute concentration $(\triangle \mathrm{POC})$ at three depths and for three management systems (MS): Pp: continuous pasture, CT: continuous cropping under conventional tillage, NT: continuous cropping under no-tillage. Vertical bars in each column indicate standard error of the mean. Different letters next to each column for each ASF (C and B) or MS (A) and for each depth indicate significant differences among ASF or MS, respectively ( $p<0.05)$. 
Higher POC content in the aggregates $>250 \mu$ m under Pp and NT agrees with other authors working under different soil and environmental conditions (Cambardella and Elliott, 1993; Six et al., 1998, 2000b; Zotarelli et al., 2007). This could have been the reason of the small change in aggregate weight of that size between wetting procedures (Figure 1C) due to the role of POC on aggregate stability (Six et al., 2000b). Pastures and no-tillage tend to increase POC content especially at 0-5 cm (Eiza et al., 2005; Domínguez et al., 2009) (Figure 3) and therefore, produce an increment in aggregate stability and SOC accrual (Carter, 2002; Eiza et al., 2006; Domínguez et al., 2008).

However, even when differing from SOC (Figure 4) and AOC (data not shown), microaggregates (50$250 \mu \mathrm{m}$ ) obtained by sieving after IW showed lower absolute concentrations of POC than those obtained after CW (Figure 5A and B). Thus, changes in POC concentration in microaggregates between wetting procedures (IW $-\mathrm{CW}$ ), were mostly negative. This disagrees with the reports of other authors (Cambardella and Elliott, 1993; Six et al., 1998, 2000b). According to those authors, it was expected that those aggregates that remained intact after IW had higher POC content, as it was observed for macroaggregates $(>250 \mu \mathrm{m})$ with some exceptions (Figure 5). However, it has also been reported (Six et al., 1998) that, during IW, some microaggregates may breakdown reducing their size though not enough to pass through the $50 \mu \mathrm{m}$ sieve. This could have freed some very fine
POC protected within them that could have not been detected when determining POC content of microaggregates after IW.

Distribution of AOC among different aggregate size categories was more uniform among management systems (data not shown) than that of SOC (Figure 4). Figures 4 and 5 showed that absolute concentration of SOC and POC in microaggregates (50$250 \mu \mathrm{m})$ were, in general, lower and higher, respectively, than in the other aggregate sizes. This means that AOC concentration in this aggregate fraction was lower than in aggregates $>250 \mu \mathrm{m}$ (data not shown), agreeing with Cozzoli et al. (2010). However, the differences IW-CW in AOC concentration (Table 2) were mostly positive and tending to be higher in microaggregates $(50-250 \mu \mathrm{m})$ than in macroaggregates $(>250 \mu \mathrm{m})$. Hence, after IW, AOC in microaggregates was in general higher than after $\mathrm{CW}$, indicating that AOC plays a very important role in their stabilization. On the other hand, in microaggregate formation and recycling, POC acts as a nucleus of formation and continues its transformation towards humification (Six et al., 1998). Despite the breakdown of microaggregates after IW being very small (Figure 1C), the partially decomposed POC freed during sieving could have suffered additional breakage and passed the $50 \mu \mathrm{m}$ sieve. Because of this, POC concentration in microaggregates after IW was lower than after CW (Figure 5). 
Table 2. Absolute concentration changes of the mineral-associated organic carbon (AOC) between two wetting procedures (by immersion - capillary), at three depths for three management systems: Pp: continuous pasture, CT: continuous cropping under conventional tillage, NT: continuous cropping under no-tillage. Different letters within each management system for each depth indicate significant differences among aggregate sizes $(p<0.05)$.

\begin{tabular}{|c|c|c|c|c|c|c|c|c|c|}
\hline \multirow{5}{*}{$\begin{array}{l}\text { Depth } \\
(\mathrm{cm})\end{array}$} & \multicolumn{9}{|c|}{ Management system } \\
\hline & \multicolumn{3}{|c|}{$\mathrm{Pp}$} & \multicolumn{3}{|c|}{$\mathrm{CT}$} & \multicolumn{3}{|c|}{ NT } \\
\hline & \multicolumn{9}{|c|}{ Aggregate size $(\mu \mathrm{m})$} \\
\hline & $>2000$ & $\begin{array}{l}250- \\
2000\end{array}$ & $50-250$ & $>2000$ & $\begin{array}{l}250- \\
2000\end{array}$ & $50-250$ & $>2000$ & $\begin{array}{l}250- \\
2000\end{array}$ & $50-250$ \\
\hline & \multicolumn{9}{|c|}{ 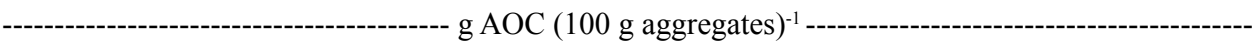 } \\
\hline $0-5$ & $0.08 \mathbf{a}$ & $0.21 \mathrm{a}$ & $0.36 \mathbf{a}$ & $0.10 \mathbf{a}$ & $0.12 \mathbf{a}$ & $0.61 \mathbf{a}$ & $0.25 \mathbf{a}$ & $0.50 \mathrm{a}$ & $0.50 \mathbf{a}$ \\
\hline $5-20$ & $0.05 \mathbf{b}$ & $0.05 \mathrm{~b}$ & $0.98 \mathbf{a}$ & $0.07 \mathbf{b}$ & $0.10 \mathbf{b}$ & $0.88 \mathbf{a}$ & $0.45 \mathbf{b}$ & $0.60 \mathrm{~b}$ & $0.97 \mathbf{a}$ \\
\hline $0-20$ & $0.06 \mathbf{b}$ & $0.09 \mathrm{~b}$ & $0.82 \mathbf{a}$ & $0.07 \mathbf{b}$ & $0.11 \mathbf{b}$ & $0.81 \mathbf{a}$ & $0.40 \mathbf{a}$ & $0.57 \mathbf{a}$ & $0.85 \mathbf{a}$ \\
\hline
\end{tabular}

Those management systems with low soil disturbance (Pp and NT) showed higher SOC and POC contents in their aggregates (Figures 4 and 5), higher proportion of stable macroaggregates, and lower changes in their amount when they were subjected to both wetting procedures (Figure 1C). The higher absolute concentration of SOC and POC in the aggregates under NT relative to under CT, indicate that the higher SOC and POC contents in the whole soil under NT (Figure 3 ) are located in aggregates of different size and are more stable than under CT (Figures 4 and 5).

\section{Conclusion}

Aggregate separation by size after different wetting procedures allowed the identification of the effect of contrasting management systems on aggregate size distribution and stability associated with them. Soil organic $\mathrm{C}$ fractionation in aggregate size categories showed that the management systems with less tillage-induced disruption (Pp and NT) did lead to higher SOC and POC contents in the macroaggregates and to increase their stability. This demon- strates that soil condition and $\mathrm{C}$ sequestration could be improved through management practices.

However, our results also showed that 15 years under continuous cropping under no-tillage after long lasting cropping under conventional tillage did not equate the soil condition under Pp, suggesting that for these Mollisols the adoption of no-tillage alone would not be enough to fully recover soil properties affected by continuous cropping.

\section{Acknowledgements}

This work was funded by the Universidad Nacional de Mar del Plata, (research projects AGR 33610 and AGR359-11), by the Instituto Nacional de Tecnología Agropecuaria (research projects PNCER-022411 and AERN-295541), and by the Fondo para la Investigación Científica y Tecnológica (research project PICT PAE 37164-Nodo 4). The authors want to express their deepest appreciation to Germán and Roberto Domínguez who built the device used to standardize the sieving procedure to separate the aggregates. 


\section{References}

Álvarez, R., Álvarez,C. R. 2000. Soil organic matter pools and their association with carbon mineralization kinetics. Soil Sci. Soc. Am. J. 64, 184-189.

Bronick, C. J., Lal, R. 2005. Soil structure and management: a review. Geoderma 124, 3-22.

Cambardella, C. A., Elliott, E. T. 1992. Particulate soil organic matter. Changes across a grassland cultivation sequence. Soil Sci. Soc. Am. J. 56, 777 783.

Cambardella, C. A., Elliott, E. T. 1993. Carbon and nitrogen distribution in aggregate from cultivated and native grassland soils. Soil Sci. Soc. Am. J. 57, 1071-1076.

Carter, M. R. 2002. Soil quality for sustainable land management: organic matter and aggregation interactions that maintain soil functions. Agron. J. 94, 38-47.

Cozzoli, M. V., Fioriti, N., Studdert, G. A., Domínguez, G. F., Eiza, M. J. 2010. Nitrógeno liberado por incubación anaeróbica y fracciones de carbono en macro- y microagregados bajo distintos sistemas de cultivo. Ciencia del Suelo 28, 155-167.

Diovisalvi, N. V., Studdert, G. A., Domínguez, G. F., Eiza, M. J. 2008. Fracciones de carbono y nitrógeno orgánicos y nitrógeno anaeróbico bajo agricultura continua con dos sistemas de labranza. Ciencia del Suelo 26, 1-11.

Domínguez, G. F., Andersen, A., Studdert, G. A. 2008. Cambios en la estabilidad de agregados en distintos sistemas de cultivo bajo siembra directa y labranza convencional. Proceedings $21^{\text {th }}$ Congreso Argentino de la Ciencia del Suelo, May 13-16, 2008, Potrero de los Funes, San Luis, Argentina (in CD- ROM).
Domínguez, G. F., Diovisalvi, N. V., Studdert, G. A., Monterubbianesi, M. G. 2009. Soil organic C and $\mathrm{N}$ fractions under continuous cropping with contrasting tillage systems on mollisols of the southeastern pampas. Soil Till. Res. 102, 93-100

Eiza, M. J., Fioriti, N., Studdert, G. A., Echeverría, H. E. 2005. Fracciones de carbono orgánico en la capa arable: efecto de los sistemas de cultivo y de la fertilización nitrogenada. Ciencia del Suelo 23, 59-67.

Eiza, M. J., Studdert, G. A., Fioriti, N., Dominguez, G. F. 2006. Estabilidad de agregados y materia orgánica total y particulada en molisoles de Balcarce. Proceedings $20^{\text {th }}$ Congreso Argentino de la Ciencia del Suelo, September 19-22, 2006, SaltaJujuy, Argentina, (in CD-ROM).

Ernst, O., Siri-Prieto, G. 2009. Impact of perennial pasture and tillage systems on carbon input and soil quality indicators. Soil Till. Res. 105, 260268.

Fabrizzi, K. P., Morón, A., García, F. O. 2003. Soil carbon and nitrogen organic fractions in degraded vs. non-degraded Mollisols in Argentina. Soil Sci. Soc. Am. J. 67, 1831-1841.

INTA. 1979. Carta de Suelos de la República Argentina. Hoja: 3757-31, Balcarce., Instituto Nacional de Tecnología Agropecuaria, Secretaría de Agricultura, Ganadería y Pesca, Buenos Aires, Argentina, $78 \mathrm{p}$.

Janzen, H. H. 2006. The soil carbon dilemma: shall we hoard it or use it? Soil Biol. Biochem. 38, 419424.

Kong, A. Y. Y., Six, J., Bryant, D. C., Denison, R. F., van Kessel, C. 2005. The relationship between carbon input, aggregation, and soil organic carbon stabilization in sustainable cropping systems. Soil Sci. Soc. Am. J. 69, 1078-1085. 
Litell, R. C., Milliken, G. S., Stroup, W. W., Wolfinger, R. D., Schabenberger, O. 2006. SAS ${ }^{\circledR}$ for Mixed Models, 2nd ed., SAS Institute Inc., Cary, $\mathrm{NC}$, USA, $633 \mathrm{p}$.

Oorts, K., Bossuyt, H., Labreuche, J., Merckx, R., Nicolardot, B. 2007. Carbon and nitrogen stocks in relation to organic matter fractions, aggregation and pore size distribution in no-tillage and conventional tillage in northern France. Eur. J. Soil. Sci. 58, 248-259.

Puget, P., Lal, R. 2005. Soil organic carbon and nitrogen in a Mollisol in central Ohio as affected by tillage and land use. Soil Till. Res. 80, 201-213.

Sainz-Rozas, H., Echeverría, H.E., Angelini, H. 2011. Niveles de carbono orgánico y pH en suelos agrícolas de la Región Pampeana y Extrapampeana argentina. Ciencia del Suelo 29, 29-37.

Schlichting, E., Blume, H.P., Stahr, K. 1995. Bodenkundliches Praktikum. Paul Parey. Hamburgo, Germany, 209 p.

Six, J., Elliott, E. T., Paustian, K. 1998. Aggregate and SOM dynamics under conventional and no-tillage systems. Soil Sci. Soc. Am J. 63, 1350-1358.

Six, J., Paustian, K., Elliott, E. T., Combrink, C. 2000a. Soil structure and organic matter: I. Distribution of aggregate-size classes and aggregateassociated carbon. Soil Sci. Soc. Am. J. 64, 681689.
Six, J., Elliott, E. T., Paustian, K. 2000b. Soil structure and soil organic matter: II. A normalized stability index and the effect of mineralogy. Soil Sci. Soc. Am. J. 64, 1042-1049.

Six, J., Conant, R. T., Paul, E. A., Paustian, K. 2002. Stabilization mechanisms of soil organic matter: Implications for C-saturation of soils. Plant Soil 241, 155-176.

Studdert, G. A., Echeverría, H. E., Casanovas, E. M. 1997. Crop-pasture rotation for sustaining the quality and productivity of a Typic argiudoll. Soil Sci. Soc. Am. J. 61, 1466-1472.

Varvel, G. E., Wilhelm, W. W. 2010. Long-term soil organic carbon as affected by tillage and cropping systems. Soil Sci. Soc. Am. J. 74, 915-921.

Wander, M. 2004. Soil organic matter fractions and their relevance to soil function. In: K. Magdoff, R. R.Weil (eds.) Soil organic matter in sustainable agriculture. CRC Press, Boca Raton, Florida, USA, pp: 67-102.

Weil, R. R., Magdoff, F. 2004. Significance of soil organic matter to soil quality and health. In: K. Magdoff, R. R.Weil (eds.) Soil organic matter in sustainable agriculture. CRC Press, Boca Raton, Florida, USA, pp: 1-43.

Zotarelli, L., Alves, B. J. R., Urquiaga, S., Boddey, R. M., Six, J. 2007. Impact of tillage and crop rotation on light fraction and intra-aggregate soil organic matter in two Oxisols. Soil Till. Res. 95, 196-205. 
